\title{
Haemofiltration for profound dialysis-induced hypotension: removal of sodium and water without blood-pressure change
}

\author{
ALEX M DAVISON， T G ROBERTS，B H MASCIE-TAYLOR，A M LEWINS
}

\begin{abstract}
Two patients with profound dialysis-induced hypotension were seen, in both of whom sequential ultrafiltration and haemodialysis failed to alleviate their symptoms; in one bicarbonate dialysis similarly produced no improvement. The hypotension was frequently severe enough to necessitate premature termination of the dialysis. Haemofiltration was associated with almost total resolution of symptoms, adequate biochemical control of uraemia, and satisfactory removal of weight gain between dialysis sessions.

Profound hypotension during dialysis may become more common as older patients enter dialysis programmes; haemofiltration is a valuable technique in such cases.
\end{abstract}

\section{Introduction}

Hypotension occurring during haemodialysis for chronic renal failure has an incidence of $20-30 \%^{12}$ and is usually associated with excessive removal of sodium and fluid. Most patients with dialysis-induced hypotension may be managed by increasing the sodium concentration in the dialysate, ${ }^{3}$ volume replacement with isotonic fluid, bicarbonate dialysis, ${ }^{4}$ or using the technique of sequential ultrafiltration and haemodialysis. ${ }^{5}$ In the past year we have seen two unusual patients, with poor myocardial function, in whom haemodialysis was regularly accompanied by profound hypotension intractable to conventional management and severe enough frequently to require premature termination of the dialysis session.

Haemofiltration is a technique that uses a highly permeable

Department of Renal Medicine, St James's University Hospital, Leeds LS9 7TF

ALEX M DAVISON, MD, FRCP, consultant renal physician

T G ROBERTS, MB, MRCP, registrar

B H MASCIE-TAYLOR, $\mathrm{MB}, \mathrm{CHB}$, registrar

A M LEWINS, SRN, nursing officer membrane that allows for rapid separation of a fluid ultrafiltrate from blood. At a blood flow rate of $200 \mathrm{ml} / \mathrm{min}$ it is possible to remove $100 \mathrm{ml}$ protein-free filtrate/min. During each treatment session an equal volume of isotonic fluid is reinfused to maintain fluid balance, and in four hours some 201 is exchanged. We report here the value of haemofiltration in the management of these two patients.

\section{Patients and methods}

Case 1-A 50-year-old woman with long-standing hypertension and chronic renal failure required haemodialysis from December 1979. She had a history of cardiovascular disease and had suffered a mild cerebrovascular accident before starting haemodialysis. An electrocardiogram obtained before the start of dialysis showed left ventricular hypertrophy and strain. Her blood pressure was controlled by atenolol $100 \mathrm{mg}$ and hydralazine $100 \mathrm{mg}$ daily.

Case 2-A 50-year-old man with long-standing hypertension and chronic renal failure required haemodialysis from June 1980 . He had poor myocardial function with mitral incompetence and left ventricular failure. Serial electrocardiograms showed left ventricular hypertrophy and strain. Shortly after the start of regular haemodialysis all hypotensive treatment was safely stopped.

Dialysis-Haemodialysis was performed with a Kiil-type dialyser (Meltec Multipoint $1 \mathrm{~m}^{2}$ ) for a scheduled four hours thrice weekly. During sequential ultrafiltration and haemodialysis the desired weight loss was calculated and achieved by initial isolated ultrafiltration and then haemodialysis performed with a disposable-type flat plate dialyser (Gambro $1.36 \mathrm{~m}^{2}$ ), the composition of the dialysate being as before (table I). Bicarbonate dialysis was performed using a Redy system and a flat plate disposable dialyser (Gambro $1.36 \mathrm{~m}^{2}$ ). Haemofiltration was performed with a Gambro AK 10 system using a Gambro fibre haemofilter of $1.2 \mathrm{~m}^{2}$ composed of styrene-acrylonitrile, polyurethane, silicone rubber, and polyamide. This filter has a high filtration characteristic, achieving a filtration rate of $100 \mathrm{ml} / \mathrm{min}$ at a blood flow of $200 \mathrm{ml} / \mathrm{min}$ and a transmembrane pressure of $400 \mathrm{~mm} \mathrm{Hg}$. The isotonic replacement fluid is reinfused throughout the procedure to maintain fluid balance, and during four hours about 201 is exchanged. The exact volume reinfused is calculated from the total volume expected to be removed less the desired fluid loss to correct for weight gain between dialysis sessions. Haemofiltration was performed for four hours thrice weekly, and the replacement fluid contained either lactate or acetate (table I). Blood sampling for creatinine, phosphate, and haemoglobin concentrations was performed before dialysis at the last treatment session of each procedure. 


\section{Results}

During conventional haemodialysis the patient in case 1 suffered frequent episodes of angina, hypotension, and cramp and regularly required isotonic infusions and premature termination of the dialysis session. The other patient also had frequent episodes of hypotension and needed isotonic infusions and early termination of dialysis (table II). Hypotension was defined as a systolic pressure of less than 110 $\mathrm{mm} \mathrm{Hg}$ or a diastolic pressure of less than $60 \mathrm{~mm} \mathrm{Hg}$, or both. In both patients blood pressure often fell below these arbitrary values within 30 minutes of the start of dialysis, with frequent impairment of consciousness.

Sequential ultrafiltration and haemodialysis diminished the severity of symptoms, but both patients continued to be severely troubled. Bicarbonate dialysis with a Redy system was performed only in case 1 , and during 13 sessions (one month) her symptoms were similar to those experienced during acetate haemodialysis.

Haemofiltration produced a considerable improvement in symptoms in both patients. The severe angina and cramps in case 1 were almost totally abolished. Haemofiltration never had to be terminated prematurely, and isotonic infusions were required only once. In case 1 there was little difference in response with either acetate- or lactatecontaining replacement fluid (in case 2 only lactate-containing fluid was used).

The weight loss achieved with haemofiltration was about twice that achieved during haemodialysis, and there was no difference between the two techniques in the biochemical control of uraemia (table III) as judged by predialysis creatinine, phosphate, and haemoglobin concentrations.

\section{Discussion}

The incidence of symptomatic hypotension during dialysis is $20-30 \%{ }^{1}$; with the increased use of dialysers with a large surface area this incidence might possibly increase. The cause of hypotension is multifactorial, but a major component is a diminished effective blood volume. In some patients the hypotension will be worsened by poor myocardial function and therefore an inability to respond by increasing cardiac output, and this may have been a factor in our patients. Symptomatic hypotension may usually be overcome by infusing isotonic fluid or mannitol, or by reducing the rate of blood flow or reducing the transmembrane pressure or both. In the two patients reported on here these measures failed to relieve the profound hypotension, and dialysis often had to be stopped prematurely.

We wondered whether the hypotensive drugs given in case 1 might have blunted the cardiovascular response to hypovolaemia but omitting these drugs on dialysis days had no effect. We recognise, however, that the beta-blockade would not have been reversed in this time.

A possible cause of vasodilatation and hypotension is the vasoactive effect of acetate. In view of this one patient (case 1 ) was transferred to bicarbonate dialysis by modifying the Redy system to accommodate a bicarbonate dialysate. This produced no improvement, contrary to the experience of Graefe et al. The place of bicarbonate in overcoming dialysis hypotension is not clear, and for this reason we did not use this technique in case 2 . In case 1 there was no difference in symptoms during haemofiltration with acetate- or lactate-containing replacement fluid. Quellhorst et $a l^{5}$ reported no symptomatic hypotension during post-dilutional haemofiltration with lactate fluid, and Shaldon $^{6}$ found that the maximal reduction in mean arterial pressure during haemofiltration with acetate fluid never exceeded $10 \%$ of the pretreatment value. It would appear, therefore, from these observations that the beneficial effect of haemofiltration cannot be attributed to avoidance of acetate, and this therefore brings into question the role of acetate in dialysis-associated hypotension.

TABLE I-Composition of dialysis fuid (mmol/l)

\begin{tabular}{|c|c|c|c|c|c|c|c|}
\hline & Sodium & Potassium & Magnesium & Calcium & Acetate & Lactate & Bicarbonate \\
\hline $\begin{array}{l}\text { Haemodialysis (acetate) } \\
\text { Haemodialysis (bicarbonate) } \\
\text { Haemofiltration (acetate) } \\
\text { Haemofiltration (lactate) }\end{array}$ & $\begin{array}{l}137 \\
130 \\
140 \\
140\end{array}$ & $\begin{array}{l}1 \cdot 5 \\
1.5 \\
1 \cdot 0 \\
1 \cdot 0\end{array}$ & $\begin{array}{l}0 \cdot 5 \\
0.5 \\
1 \cdot 0 \\
0 \cdot 8\end{array}$ & $\begin{array}{l}1 \cdot 5 \\
1.5 \\
2 \cdot 0 \\
1 \cdot 6\end{array}$ & $\begin{array}{l}35 \\
35\end{array}$ & 33 & 30 \\
\hline
\end{tabular}

Conversion: SI to traditional units-Sodium, potassium, bicarbonate: $1 \mathrm{mmol} / 1=1 \mathrm{mEq} / 1$. Magnesium: $1 \mathrm{mmol} / 1 \approx 2.4 \mathrm{mg} / 100 \mathrm{ml}$. Calcium: $1 \mathrm{mmol} / 1 \approx 4 \mathrm{mg} / 100 \mathrm{ml}$. Acetate: $1 \mathrm{mmol} / 1 \approx 5.9 \mathrm{mg} / 100 \mathrm{ml}$. Lactate: $1 \mathrm{mmol} / 1 \approx 9 \mathrm{mg} / 100 \mathrm{ml}$.

TABLE II-Incidence of symptomatic episodes during haemodialysis, bicarbonate dialysis, sequential ultrafiltration and dialysis, and haemofiltration. (Figures are percentages (and proportions))

\begin{tabular}{|c|c|c|c|c|c|c|c|c|c|c|}
\hline & \multicolumn{2}{|c|}{ Hypotension* } & \multicolumn{2}{|c|}{ Angina } & \multicolumn{2}{|c|}{ Cramp } & \multicolumn{2}{|c|}{$\begin{array}{c}\text { Isotonic infusions } \\
\text { required }\end{array}$} & \multicolumn{2}{|c|}{$\begin{array}{l}\text { Shortened dialysis } \\
\text { required }\end{array}$} \\
\hline & Case 1 & Case 2 & Case 1 & Case 2 & Case 1 & Case 2 & Case 1 & Case 2 & Case 1 & Case 2 \\
\hline $\begin{array}{l}\text { Haemodialysis } \\
\text { Bicarbonate haemodialysis } \\
\text { Sequential treatment } \\
\text { Haemofiltration (lactate) } \\
\text { Haemofiltration (acetate) }\end{array}$ & $\begin{array}{l}33(10 / 30) \\
62(8 / 13) \\
36(9 / 25) \\
10(4 / 40) \\
5(1 / 19)\end{array}$ & $\begin{array}{l}58(22 / 38) \\
77(10 / 13) \\
17(5 / 30)\end{array}$ & $\begin{array}{c}37(11 / 30) \\
0 \\
40(10 / 25) \\
5(2 / 40) \\
0\end{array}$ & $\begin{array}{l}0 \\
0 \\
0\end{array}$ & $\begin{array}{l}27(8 / 30) \\
23(3 / 13) \\
56(14 / 25) \\
5(2 / 40) \\
5(1 / 19)\end{array}$ & $\begin{array}{l}5(2 / 38) \\
8(1 / 13) \\
0\end{array}$ & $\begin{array}{l}47(14 / 30) \\
46(6 / 13) \\
88(22 / 25) \\
15(6 / 40) \\
5(1 / 19)\end{array}$ & $\begin{array}{l}68(26 / 38) \\
77(10 / 13) \\
17(5 / 30)\end{array}$ & $\begin{array}{c}60(18 / 30) \\
23(3 / 13) \\
80(20 / 25) \\
0 \\
0\end{array}$ & $\begin{array}{c}13(5 / 38) \\
23(3 / 13) \\
0\end{array}$ \\
\hline
\end{tabular}

*Defined as systolic pressure less than $110 \mathrm{~mm} \mathrm{Hg}$ or diastolic pressure less than $60 \mathrm{~mm} \mathrm{Hg}$, or both.

TABLE III-Weight loss, blood pressure, and creatinine, phosphate, and haemoglobin concentrations during each procedure

\begin{tabular}{|c|c|c|c|c|c|c|c|c|c|c|c|c|}
\hline & \multicolumn{2}{|c|}{$\underset{(\mathbf{k g})^{*}}{\text { Weight loss }}$} & \multicolumn{4}{|c|}{$\begin{array}{l}\text { Blood pressure } \\
(\mathrm{mm} \mathrm{Hg})^{*}\end{array}$} & \multicolumn{2}{|c|}{$\begin{array}{l}\text { Creatinine } \\
(\mu \mathrm{mol} / \mathrm{l}) \dagger\end{array}$} & \multicolumn{2}{|c|}{$\begin{array}{l}\text { Phosphate } \\
(\mathrm{mmol} / \mathrm{l}) \dagger\end{array}$} & \multicolumn{2}{|c|}{$\begin{array}{c}\text { Haemoglobin } \\
(\mathrm{g} / \mathrm{dl}) \dagger\end{array}$} \\
\hline & \multirow{2}{*}{ Case 1} & \multirow{2}{*}{ Case 2} & \multicolumn{2}{|c|}{ Case 1} & \multicolumn{2}{|c|}{ Case 2} & \multirow{2}{*}{ Case 1} & \multirow{2}{*}{ Case 2} & \multirow{2}{*}{ Case 1} & \multirow{2}{*}{ Case 2} & \multirow{2}{*}{ Case 1} & \multirow{2}{*}{ Case 2} \\
\hline & & & Before & After & Before & After & & & & & & \\
\hline $\begin{array}{l}\text { Haemodialysis } \\
\text { Bicarbonate dialysis }\end{array}$ & $\begin{array}{l}0.9 \\
1.5\end{array}$ & $1 \cdot 23$ & $\begin{array}{l}164 / 93 \\
166 / 98\end{array}$ & $\begin{array}{l}138 / 80 \\
133 / 79\end{array}$ & $136 / 84$ & $104 / 64$ & $\begin{array}{l}1244 \\
1287\end{array}$ & 838 & $3 \cdot 1$ & $1 \cdot 7$ & $7 \cdot 1$ & $5 \cdot 7$ \\
\hline $\begin{array}{l}\text { Sequential treatment } \\
\text { Haemofiltration (lactate) } \\
\text { Haemofiltration (acetate) }\end{array}$ & $\begin{array}{l}1 \cdot 0 \\
2 \cdot 1 \\
1 \cdot 6\end{array}$ & $\begin{array}{l}2 \cdot 1 \\
2 \cdot 30\end{array}$ & $\begin{array}{l}172 / 104 \\
164 / 98 \\
168 / 95\end{array}$ & $\begin{array}{l}150 / 86 \\
146 / 85 \\
154 / 90\end{array}$ & $\begin{array}{l}170 / 100 \\
150 / 88\end{array}$ & $\begin{array}{l}110 / 70 \\
100 / 60\end{array}$ & $\begin{array}{l}1210 \\
1048 \\
1097\end{array}$ & $\begin{array}{l}916 \\
928\end{array}$ & $\begin{array}{l}2 \cdot 7 \\
2 \cdot 8 \\
2 \cdot 7\end{array}$ & $\begin{array}{l}1.9 \\
1.9\end{array}$ & $\begin{array}{l}7 \cdot 2 \\
6 \cdot 9 \\
6 \cdot 6\end{array}$ & $\begin{array}{l}6 \cdot 0 \\
5 \cdot 6\end{array}$ \\
\hline
\end{tabular}

* Values given as means for duration of procedure.

Conversion: SI to traditional units-Creatinine: $1 \mu \mathrm{mol} / 1 \approx 11.3 \mu \mathrm{g} / 100 \mathrm{ml}$. Phosphate: $1 \mathrm{mmol} / 1 \approx 3.1 \mathrm{mg} / 100 \mathrm{ml}$ 
Bergstrom $e \mathrm{al}^{7}$ reported the value of sequential ultrafiltration and haemodialysis in overcoming dialysis-induced hypotension. During isolated ultrafiltration peripheral vascular resistance increases, whereas in acetate dialysis no such increase occurs. ${ }^{8}$ The symptoms of our two patients did not appear to improve during sequential treatment, though we have found this a most useful technique in many other patients.

Haemofiltration is a fairly new technique that uses highly permeable membranes to produce an ultrafiltrate of blood. This technique has been reported as producing a considerable decrease in symptomatic hypotensive episodes as well as providing a most satisfactory method of controlling severe hypertension in patients receiving dialysis. ${ }^{9}$ Why hremofiltration should be so effective in controlling hypotension is not known, but it may be due to removal of some vasoactive "middle molecule" or to reduced production of cell-liberated materials such as prostacyclin. In the two patients reported on here satisfactory weight reduction and biochemical control of uraemia were achieved with haemofiltration with almost total abolition of their dialysisinduced symptoms.

Profound hypotension impairing consciousness during dialysis is unusual but may become more common with the increasing number of older patients entering dialysis programmes. We wish to draw attention to the value of haemofiltration in managing such patients. In addition, this method of removing sodium and water without affecting blood pressure may be of considerable advantage to patients overloaded with non-uraemic fluid in whom conventional diuretic treatment is ineffective or associated with unacceptable complications of volume depletion.
We gratefully acknowledge patient co-operation during this study and thank the nursing and technical staff responsible for the patient care. The support of the Yorkshire Kidney Research Fund is much appreciated.

Reprint requests should be sent to Dr A M Davison, St James's University Hospital, Beckett Street, Leeds LS9 7TF.

\section{References}

1 Rosa AA, Fryd DS, Kjellstrand CM. Dialysis symptoms and stabilisation in long-term dialysis. Arch Intern Med 1980;140:804-7.

${ }^{2}$ Rubin LJ, Gutman RA. Hypotension during haemodialysis. Kidney 1978; $11: 21-4$.

${ }^{3}$ Levine J, Falk B, Henriquez M, Raja RM, Kramer MS, Rosenbaum JL. Effects of varying dialysate sodium using large surface area dialysers. Trans Am Soc Artif Intern Organs 1978;24:139-41.

${ }^{4}$ Graefe U, Milutinovich J, Follette WC, Vizzo JE, Babb AL, Scribner BH. Less dialysis-induced morbidity and vascular instability with bicarbonate in dialysate. Ann Intern Med 1978;88:332-6.

${ }^{5}$ Quellhorst E, Riger J, Doht B, et al. Treatment of chronic uraemia by an ultrafiltration kidney in first clinical experience. Proc Eur Dial Transplant Assoc 1976;13:314-21.

${ }^{6}$ Shaldon S. Progress in haemodialysis. Nephron 1981 ;27:2-6.

7 Bergstrom J, Asaba N, Fürst P, Oulès R. Dialysis ultrafiltration and blood pressure. Proc Eur Dial Transplant Assoc 1976;13:293-300.

8 Wehle B, Asaba H, Castenfurs J, et al. Haemodynamic changes during sequential ultrafiltration dialysis. Kidney Int 1979;15:411-8.

9 Henderson LW, Ford CA, Lysaght MJ, Grossman RA, Silverstein ME. Preliminary observations on blood pressure response with maintenance diafiltration. Kidney Int 1975;7:S413-7.

\title{
Inappropriate secretion of antidiuretic hormone treated with frusemide
}

\author{
GUY DECAUX, YVES WATERLOT, FRANÇOISE GENETTE, ROGER HALLEMANS, \\ JEAN CLAUDE DEMANET
}

\begin{abstract}
Seven out of nine patients with chronic inappropriate secretion of antidiuretic hormone were successfully treated with $40 \mathrm{mg}$ frusemide daily. One patient needed $80 \mathrm{mg}$, and the remaining patient achieved only a small increase in diuresis after $40 \mathrm{mg}$ frusemide; this was probably related to his low creatinine clearance. In order to maintain a salt intake high enough to compensate for the loss of urine electrolytes 3 to $6 \mathrm{~g}$ sodium chloride was added as tablets to the sodium-free diet in six patients. Hypokalaemia occurred in five patients but was easily corrected with either supplements of potassium chloride or a potassium-sparing diuretic.
\end{abstract}

\footnotetext{
Department of Internal Medicine, Saint-Pierre University Hospital, 322 Rue Haute, Brussels 1000, Belgium, and Institute of Interdisciplinary Research, School of Medicine, Free University of Brussels, Brussels, Belgium GUY DECAUX, MD, assistant YVES WATERLOT, MD, assistant FRANCOISE GENETTE, $M D$, assistant ROGER HALLEMANS, MD, assistant

JEAN CLAUDE DEMANET, $M D$, PHD, professor of internal medicine, University Department of Anaesthesia, Saint-Pierre University Hospital
}

These findings add further weight to evidence that frusemide is a good alternative for the treatment of patients with inappropriate secretion of antidiuretic hormone who cannot tolerate water restriction.

\section{Introduction}

Water restriction is the cornerstone of treatment for the syndrome of inappropriate secretion of antidiuretic hormone. ${ }^{1}$ When restriction must be drastic or is difficult for the patient to tolerate demeclocycline ${ }^{2}$ or urea $^{3}$ may be tried. We successfully treated a patient with symptoms of inappropriate secretion of antidiuretic hormone using a single oral dose of $40 \mathrm{mg}$ frusemide, ${ }^{4}$ the principle being to induce a water diuresis while compensating for electrolyte losses by ensuring a sufficiently high salt intake. We have now extended the observations to nine patients.

\section{Patients and methods}

We treated nine patients with chronic inappropriate secretion of antidiuretic hormone due to organic brain disease (three cases) and inoperable oat-cell carcinoma of bronchus (six) who had continued to have serum sodium concentrations below $125 \mathrm{mmol}(\mathrm{mEq}) / 1$ after five days of water restriction. All were given $40 \mathrm{mg}$ frusemide by 